\title{
FAKTOR-FAKTOR YANG MEMPENGARUHI INTENSITAS PERILAKU WAJIB PAJAK BADAN DALAM PENGGUNAAN E-FILING SPT ( Studi Pada Kantor Pelayanan Pajak Pratama Raba Bima )
}

\author{
R . Ayu Ida Aryani \\ Akuntansi Universitas Bumigora Mataram \\ ayu.aryani@universitasbumigora.ac.id
}

\begin{abstract}
The recent study intends to uncover and analyze the effect of the issues relating to utility perception, practical perception, security and confidentiality, and taxpayers'knowledgeaboutinformation technology on the intensity of corporate taxpayers'behaviors in utilizing E-Filling. The study is conducted in three regencies, such as Dompu, Bima and the city of Bima. The population of the current study are 770 corporate taxpayers which are registered in Raba Bima Primary Tax Office and have utilized e-filling. There are 89 respondents involved which are generated by using SlovinTechnique. SPSS V.20 is applied to analyze data. The findings of the current study indicate that the issues relating to utility perception, practical perception, security and confidentiality have positive and significant impact on the intensity of corporate taxpayers' behaviors in utilizing e - filling. Meanwhile, taxpayers' knowledge about information technology has not positive and significant influence on the intensity of corporate tax payers' behaviors in utilizing e-filling. The implication of the current study for Raba Bima Primary Tax Office is that the tax office should consider the issues relating to utility perception, practical perception, security and confidentiality, and taxpayers' knowledge about information technology in order to maximize the successfulness of utilizing e-filling and be adopted by entire corporate taxpayers.
\end{abstract}

Keywords : Utility Perception, Practial Perception, Security and Confidentiality, Taxpayers' Knowledge about Information Technology, Taxpayers' Behavior Intensity in Utilizing EFiling

\section{PENDAHULUAN}

Penerimaan dari sektor perpajakan memegang peranan penting untuk kelangsungan sistem pemerintahan suatu negara, karena penerimaan terbesar suatu negara adalah bersumber dari pajak. Penerimaan negara yang bersumber dari sektor pajak akan digunakan untuk pembiayaan umum dari segala kegiatan pemerintah bahkan menjadi salah satu tolak ukur dari keberhasilan suatu perekonomian suatu Negara.

Berdasarkan Peraturan Direktorat Jenderal Pajak Nomor KEP-05 / PJ / 2005 tanggal 12 Januari 2005 tentang Prosedur Penyerahan SPT secara elktronik (e-filing) melalui Perusahaan Penyedia Layanan Aplikasi (ASP), e-filing merupakan suatu cara penyampaian Surat Pemberitahuan (SPT) secara elektronik yang dilakukan secara online dan real time melalui internet pada website Direktorat Jenderal Pajak atau Application Service Provider (ASP).

Penggunaan $e$-filing bertujuan untuk menciptakan administrasi perpajakan yang lebih tertib dan transparan dapat dicapai, selain itu untuk memperoleh kemudahan dalam memenuhi kewajiban perpajakan. Dengan adanya sistim e-filing wajib pajak mendapatkan efisiensi dan efektivitas dalam melakukan proses pelaporan SPT tanpa perlu mengkhawatirkan jam kerja operasional kantor pajak karena wajib pajak dapat menggunakan $e$-filing tanpa perlu datang ke kantor pajak, dan sistim $e$ - filing 
membantu waktu yang dibutuhkan Wajib Pajak untuk menyiapkan, memproses, dan melaporkan SPT ke KPP secara benar dan tepat waktu. Pelaporan SPT secara komputerisasi memiliki manfaat yang lebih besar bagi Wajib Pajak maupun Direktorat Jenderal Pajak .

Fenomena yang terjadi dalam prakteknya saat ini tidak semua wajib pajak wajib menggunakan $e$ filing karena kurangnya sosialisasi dari Direktorat Jenderal Pajak atau wajib pajak tidak dapat menerima teknologi baru untuk melaporkan pajak mereka (Laihad, 2013). Pola pikir Wajib Pajak yang masih menganggap penggunaan sistem komputer dalam pelaporan SPT lebih sulit dibandingkan dengan sistem manual. Partisipasi wajib pajak dalam penggunaan e-filing masih belum maksimal sehingga pengembalian yang diterima Direktorat Jenderal Pajak (DJP) rendah (Dewi dan Ratih, 2009).

Suatu sistem informasi dikatakan baik jika sistem keamanan reliabel, dapat dilihat melalui data pengguna yang disimpan oleh sistem formasi. Data pengguna harus dirahasiakan melalui data yang disimpan oleh sistem sehingga pihak lain tidak dapat mengaksesnya. Penelitian ini bertujuan untuk mengetahui dan menganalisis pengaruh persepsi kegunaan, persepsi kemudahan, keamanan dan kerahasiaan, pengetahuan wajib pajak pada ilmu teknologi terhadap intensitas perilaku wajib pajak badan dalam penggunaan $e$-filing.

Pertimbangan dalam penelitian ini adalah pentingnya penggunaan e-filing untuk wajib pajak, hasilnya diharapkan dapat memberikan referensi bagi Direktorat Jenderal Pajak dalam memberikan layanan dalam sistem informasi dan pemeliharaan sistem informasi terkait $e$-filing, sehingga bahwa wajib pajak yang melaporkan pajaknya akan merasa nyaman menggunakan layanan yang diberikan oleh Direktorat Jenderal Pajak (DJP) khususnya penggunaan e-filing. Dampak selanjutnya adalah wajib pajak akan mendapatkan lebih banyak manfaat tentang penggunaan $e$-filing karena merupakan kewajiban yang ditetapkan oleh undang-undang perpajakan. Teknik analisis data dalam penelitian menggunakan regresi linier berganda, berdasarkan penjelasan di atas, maka masalah utama yang akan dibahas pada penelitian ini adalah: Apakah persepsi kegunaan, persepsi kemudahan, keamanan dan kerahasiaan, pengetahuan wajib pajak pada ilmu teknologi berpengaruh terhadap intensitas perilaku wajib pajak badan dalam penggunaan $e$-filing ?

\section{METODE PENELITIAN}

\section{1). Jenis Pnelitian}

Penelitian ini adalah penelitian kuantitatif menekankan pada pengujian teori melalui pengukuran variabel-variabel penelitian dengan angka dan analisa data dengan prosedur statistik (Indriantoro dan Supomo, 2014:12). Berdasarkan tingkatannya, penelitian ini termasuk penelitian explanatory (penjelasan) yaitu penelitian untuk menguji hipotesis yang menyatakan hubungan sebab akibat antara dua variabel atau lebih (Sukandarrumidi, 2006:105). Alasan memilih jenis penelitian ini adalah untuk menguji hipotesis yang diajukan agar dapat menjelaskan hubungan korelasi variabel independen (variabel bebas) terhadap variabel dependen (variabel terikat).

\section{2). Lokasi Penelitian}

Penelitian dilakukan di wilayah kota dan kabupaten yang meliputi Kabupaten Dompu, Kabupaten Bima dan Kota Bima. Beberapa perhatian dan pertimbangan mendasari pemilihan lokasi dalam penelitian ini adalah, rendahnya pengetahuan wajib pajak mengenai tekhnologi baru, rendahnya intensitas penggunaan $e$-filing.

\section{3). Populasi dan Sampel}

Populasi menurut sugiyono (2014:115).adalah wilayah generalisasi yang terdiri atas obyek atau subyek yang mempunyai kualitas atau karakteristik tertentu yang ditetapkan oleh peneliti untuk dipelajari dan ditarik kesimpulannya, Populasi dalam penelitian ini adalah jumlah Wajib Pajak Badan yang terdaftar di KPP Pratama Raba Bima yang telah menggunakan e-filing tahun 2016 berjumlah 770 Wajib Pajak, setelah jumlah sampel ditentukan atau diperoleh, selanjutnya ditentukan melalui tekhnik proposional stratified random sampling yaitu tehnik pengambilan sampel secara proposional untuk mendapatkan sampel yang representative, dapat dilihat pada tabel 1. berikut : 
Tabel 1 Jumlah Populasi

Jumlah WP Badan terdaftar di KPP

Paratama Raba Bima menggunakan efiling

\begin{tabular}{lcc} 
Wilayah & Populasi & Sampel \\
\hline Dompu & 401 & 46 \\
Kabupaten & 187 & 22 \\
Bima & 182 & 21 \\
Kota Bima & 770 & 89 \\
\multicolumn{1}{c}{ Total } & &
\end{tabular}

Ukuran jumlah responden dihitung berdasarkan rumus Slovin, dimana jumlah sampel ditentukan berdasarkan pendugaan proporsi populasi yang dapat dihitung seperti berikut :

$$
n=\frac{\mathrm{N}}{\left(1+\mathrm{N}(\mathrm{e})^{2}\right)}
$$

Keterangan :

$\mathrm{N}=$ Jumlah Populasi

$\mathrm{n}=$ Ukuran sampel

$\mathrm{e}=$ Kelonggaran ketelitian karena kesalahan pengambilan sampel yang ditolerir $(10 \%$ atau 0,1$)$

\section{4). Teknik Pengumpulan Data}

Teknik pengumpulan data yang digunakan dalam penelitian ini adalah :

a. Kuisioner, yaitu teknik pengumpulan data yang dilakukan dengan cara memberi seperangkat pertanyaan atau pernyataan tertulis kepada responden untuk dijawab (Sugiyono, 2014:142). Sebelum kuisioner dibagikan kepada responden dilakukan pilot tes terlebih dahulu yang bertujuan untuk melihat pemahaman responden atas penggunaan kalimat dalam kuisioner untuk mengurangi bias respon.

b. Studi kepustakaan, yaitu suatu cara pengumpulan data yang bersumber dari penelaahan kepustakaan berupa jurnal-jurnal, laporan-laporan, dan referensi lainnya yang ada hubungannya dengan masalah yang diteliti.

\section{5). Definisi Operasional Variabel}

Definisi operasional variabel diperlukan untuk memberikan gambaran yang jelas dan memudahkan pelaksanaan penelitian ini terhadap variabel yang akan diteliti sebagai dasar dalam penyusunan kuisioner penelitian. Definisi operasional dari masing-masing variabel dapat dijelaskan sebagai berikut :

\section{a). Persepsi Kegunaan}

Persepsi Kegunaan merupakan tingkat dimana individu percaya bahwa penggunaan sistim informasi atau teknologi informasi tertentu akan meningkatkan kinerja hidup maupun pekerjaan pengguna (Chen et.al :2011). Persepsi kegunaan secara langsung dapat mempengaruhi niat untuk mencoba dan menggunakan sistim e-filing, jika wajib pajak merasakan manfaatnya, akan berniat menggunakan sistim e-filing, sebaliknya jika Wajib Pajak tidak merasakan manfaat sistem $e$-filing maka tidak akan berniat untuk menggunakanmnya (Susanto, 2011) 
b). Persepsi Kemudahan

Persepsi kemudahan dalam penggunaan sebuah teknologi didefinisikan sebagai suatu ukuran dimana individu percaya bahwa sistem teknologi dapat dengan mudah dipahami dan digunakan (Davis, 1989). Suatu sistem dapat dikatakan berkualitas jika sistem tersebut dirancang untuk memenuhi kepuasan pengguna melalui kemudahan dalam menggunakan sistem tersebut. Kemudahan penggunaan dalam konteks ini bukan saja kemudahan untuk mempelajari dan menggunakan suatu sistem tetapi juga mengacu pada kemudahan dalam melakukan suatu pekerjaan atau tugas dimana pemakaian suatu sistem akan semakin memudahkan seseorang dalam bekerja dibanding mengerjakan secara manual (Pratama, 2008 dalam Gowinda, 2010).

c). Keamanan dan Kerahasiaan

Hamlet dan Strube (2000) mendefinisikan keamanan dan kerahasiaan yaitu keamanan sebagai pengguna sistim informasi itu aman, resiko kehilangan data atau informasi sangat kecil, dan resiko pencurian rendah sedangkan kerahasiaan apabila ada jaminan kerahasiaan segala hal yang berkaitan dengan informasi pribadi pengguna. Menurut (Dewi, 2009) keamanan sistem ini dapat dilihat melalui data pengguna yang aman disimpan oleh suatu sistem informasi, data pengguna ini harus terjaga kerahasiaannya dengan cara data disimpan oleh sistem sehingga pihak lain tidak dapat mengakses data pengguna secara bebas.

d). Pengetahuan Wajib Pajak terhadap IT

Pengetahuan ilmu dan teknologi yaitu suatu sumber informasi yang dapat meningkatkan pengetahuan ataupun wawasan seseorang dibidang teknologi. Dapat juga dikatakan, merupakan segala sesuatu yang berhubungan dengan teknologi, baik itu penemuan yang terbaru yang bersangkutan dengan teknologi ataupun perkembangan dibidang teknologi itu sendiri. (Horton.P.B dan Chester.L.H, ).

e). Intensitas Perilaku Wajib Pajak dalam Penggunaan $e$-filing

Intensitas perilaku merupakan ukuran kekuatan untuk menunjukkan bahwa seberapa sering Wajib Pajak melaporkan pajaknya menggunakan e-filing (Desmayanti, Zulaikha, 2012).Intensitas perilaku merupakan kelanjutan dari minat (intention) dimana minat adalah keinginan untuk melakukan perilaku. Jadi, intensitas adalah perilaku individu dalam melakukan suatu hal secara terus- menerus.

\section{6). Prosedur Analisis Data}

Prosedur analisis data dalam penelitian ini menggunakan pendekatan regresi linier berganda. Untuk keabsahan dari hasil analisis regresi berganda terlebih dahulu dilakukan uji kualitas instrument pengamatan, uji normalitas data dan uji asumsi klasik, dengan menggunakan program SPSS versi 16.0. Model analisis regresi linier berganda dalam penelitian ini dirumuskan sebagai berikut :

$$
\mathrm{Y}=\alpha+\beta_{1} \mathrm{X}_{1}+\beta_{2} \mathrm{X}_{2}+\beta_{3} \mathrm{X}_{3}+\beta_{4} \mathrm{X}_{4}+\mathrm{e}
$$

\section{Keterangan:}

$\begin{array}{ll}\mathrm{Y} & =\text { Intensitas Perilaku dalam penggunaan } e \text {-filing } \\ \alpha & =\text { Kostanta } \\ \beta 1, \beta 2, \beta 3 & =\text { Koefisien regresi } \\ \mathrm{X} 1 & =\text { Persepsi Kegunaan } \\ \mathrm{X} 2 & =\text { Persepsi Kemudahan } \\ \mathrm{X} 3 & =\text { Keamanan dan Kerahasiaan } \\ \mathrm{X} 4 & =\text { Pengetahuan Wajib Pajak terhadap IT } \\ \mathrm{e} & =\text { Error }\end{array}$

\section{Uji Validitas}

Uji Validitas digunakan untuk mengukur valid tidaknya suatu item partanyaan kuisioner. Suatu kuisioner dikatakan valid jika pernyataan pada kuisioner mampu mengungkapkan sesuatu yang akan diukur oleh kuisioner tersebut (Ghozali, 2005). Apabila nilai kosefisien korelasi $r$ hitung $>r$ tabel 
maka dapat diambil kesimpulan bahwa item tersebut adalah valid, demikian juga sebaliknya jika koefisien $\mathrm{r}$ hitung $<\mathrm{r}$ tabel maka dapat diambil kesimpulan bahwa item tersebut adalah tidak valid.

(Ghozali, 2016:53).

\section{Uji Reliabilitas}

Uji Reliabilitas untuk mengukur konsisten tidaknya sebuah jawaban seseorang terhadap item-item pertanyaan didalam sebuah angket atau kuisioner (Suliyanto, 2006:53). Uji Reliabilitas instrument penelitian dengan melihat koefisien cronbach alfa untuk semua kuisioner dari variabel. Suatu instrumenatau kuisioner dikatakan reliabel jika nilai Crombach Alpha > 0,60 (Ghozali, 2016:48)

\section{HASIL DAN PEMBAHASAN}

Hasil Penelitian

Tabel 2

Rekapitulasi Hasil Uji Validitas Instrument masing-masing Variabel

\begin{tabular}{|c|c|c|c|c|}
\hline Variabel & Item & r-hit & Keputusan & Keterangan \\
\hline \multirow{4}{*}{ Kegunaan } & $\mathrm{X}_{1 \_1}$ & 0.503 & Valid & r-hit > r-kritis \\
\hline & $\mathrm{X}_{1 \_2}$ & 0.426 & Valid & r-hit > r-kritis \\
\hline & $\mathrm{X}_{1 \_} 3$ & 0.423 & Valid & r-hit > r-kritis \\
\hline & $\mathrm{X}_{1 \_4}$ & 0.48 & Valid & r-hit > r-kritis \\
\hline \multirow{4}{*}{ Kemudahan } & $\mathrm{X}_{2 \_} 1$ & 0.615 & Valid & r-hit > r-kritis \\
\hline & $X_{2 \_} 2$ & 0.568 & Valid & r-hit > r-kritis \\
\hline & $\mathrm{X}_{2 \_} 3$ & 0.517 & Valid & r-hit > r-kritis \\
\hline & $X_{2 \_} 4$ & 0.575 & Valid & r-hit > r-kritis \\
\hline \multirow{3}{*}{$\begin{array}{c}\text { Keamanan dan } \\
\text { Kerahasiaan }\end{array}$} & $\mathrm{X}_{3 \_} 1$ & 0.458 & Valid & r-hit > r-kritis \\
\hline & $X_{3 \_} 2$ & 0.458 & Valid & r-hit $>$ r-kritis \\
\hline & $\mathrm{X}_{3 \_} 3$ & 0.427 & Valid & r-hit $>$ r-kritis \\
\hline \multirow{3}{*}{ Pengetahuan tentang IT } & $\mathrm{X}_{4 \_1}$ & 0.426 & Valid & r-hit > r-kritis \\
\hline & $X_{4 \_2}$ & 0.418 & Valid & r-hit > r-kritis \\
\hline & $X_{4 \_} 3$ & 0.402 & Valid & r-hit > r-kritis \\
\hline \multirow{3}{*}{$\begin{array}{c}\text { Intensitas Perilaku WP } \\
\text { Badan Penggunaan } \\
\text { E-Filing }\end{array}$} & Y_1 & 0.394 & Valid & r-hit > r-kritis \\
\hline & Y_2 & 0.432 & Valid & r-hit > r-kritis \\
\hline & Y_3 & 0.412 & Valid & r-hit > r-kritis \\
\hline
\end{tabular}

Hasil pengujian validitas menunjukkan bahwa semua item pernyataan untuk semua variabel penelitian ini memiliki nilai r-hitung lebih besar dari pada nilai r-kritis. Karena itu dapat disimpulkan bahwa seluruh item pernyataan telah memenuhi kriteria validitas atau dianggap valid.

Tabel 3

Rekapitulasi Hasil Uji Reliabilitas Instrument Penelitian

\begin{tabular}{clcc} 
No & \multicolumn{1}{c}{ Variabel } & Cronbach's alpha & Keputusan \\
\hline 1 & Kegunaan & 0.672 & Reliabel \\
\hline 2 & Kemudahan & 0.768 & Reliabel \\
\hline 3 & Keamanan dan Kerahasiaan & 0.644 & Reliabel \\
\hline 4 & Pengetahuan tentang IT & 0.607 & Reliabel \\
\hline 5 & $\begin{array}{l}\text { Intensitas Perilaku WP } \\
\text { Dalam Penggunaan E-Filing }\end{array}$ & 0.604 & Reliabel \\
\hline
\end{tabular}

Semua instumen variabel penelitian yang digunakan dalam penelitian memiliki nilai Cronbach's alpha lebih besar dari pada 0,6. Sehingga dapat dinyatakan bahwa semua instrumen telah memenuhi syarat reliabilitas. 
Tabel 4

Hasil Uji Normalitas Residual menggunakan Uji Kolmogorov-Sminov Tes

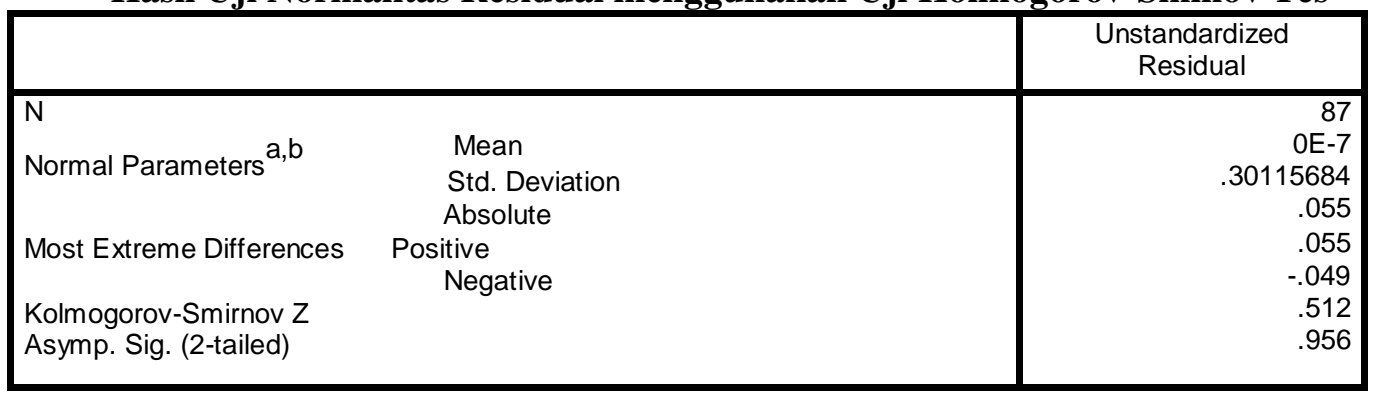

Hasil uji Kolmogorov-Smirnov pada tabel di atas menunjukkan nilai p sebesar 0,956. Berdasarkan kaidah, nilai $\mathrm{p}$ tersebut lebih besar daripada 0,05 sehingga dapat disimpulkan bahwa variabel pengganggu atau nilai residual tidak terstandar terdistribusi normal.

Tabel 5

Rekapitulasi Hasil Heteroskedastisitas Nilai Absolut Residual

\begin{tabular}{lcccc}
\hline \multicolumn{1}{c}{ Variabel Independen } & $\mathrm{t}$ & $\mathrm{p}($ Sig) & Keputusan & Keterangan \\
\hline Kegunaan & .233 & .817 & Non Heteroskedastisitas & $\mathrm{p}<0,05$ \\
\hline Kemudahan & -.571 & .570 & Non Heteroskedastisitas & $\mathrm{p}<0,05$ \\
Keamanan dan Kerahasiaan & -.745 & .459 & Non Heteroskedastisitas & $\mathrm{p}<0,05$ \\
\hline Pengetahuan tentang IT & 1.477 & .143 & Non Heteroskedastisitas & $\mathrm{p}<0,05$ \\
\hline
\end{tabular}

Tabel 5 mengindikasikan bahwa semua variabel independen memiliki nilai $\mathrm{p}<0,05$. Berdasarkan kaidah, maka dapat disimpulkan bahwa tidak terdapat masalah heteroskedastisitas pada nilai residual yang dihasilkan, dengan kata lain hasil analisis regresi tidak mengandung masalah heteroskedastisitas.

Tabel 6

Hasil Uji Multikolinearitas

\begin{tabular}{lccl}
\hline \multicolumn{1}{c}{ Variabel Dependen } & Tolerance & VIF & Keputusan \\
\hline Kegunaan & 0,893 & 1,119 & Non Multikolinearitas \\
\hline Kemudahan & 0,735 & 1,360 & Non Multikolinearitas \\
\hline Keamanan dan Kerahasiaan & 0,743 & 1,345 & Non Multikolinearitas \\
\hline Pengetahuan tentang IT & 0,805 & 1,242 & Non Multikolinearitas \\
\hline
\end{tabular}

Berdasarkan tabel 6 di atas menunjukkan bahwa seluruh variabel independen mempunyai nilai VIF yang kurang dari 10 dan nilai tolerance lebih besar dari 0,10 , berarti seluruh variabel independen yang digunakan pada model persamaan regresi tidak ada multikolinearitas (tidak ada hubungan yang sangat kuat antara variabel independen).

Tabel 7

Hasil Analisis Regresi Linear Berganda

\begin{tabular}{|c|c|c|c|c|c|}
\hline \multirow{2}{*}{\multicolumn{2}{|c|}{ Model }} & \multicolumn{2}{|c|}{ Unstandardized Coefficients } & \multirow{2}{*}{$\begin{array}{c}\text { Standardized } \\
\text { Coefficients } \\
\text { Beta }\end{array}$} & \multirow[t]{2}{*}{$t$} \\
\hline & & $\mathrm{B}$ & Std. Error & & \\
\hline \multirow{5}{*}{1} & (Constant) & .328 & .360 & & .910 \\
\hline & Kegunaan & .254 & .080 & .250 & 3.175 \\
\hline & Kemudahan & .329 & .070 & .412 & 4.734 \\
\hline & Keamanan \& Kerahasiaan & .235 & .077 & .262 & 3.028 \\
\hline & Pengetahuan IT & .107 & .083 & .107 & 1.293 \\
\hline
\end{tabular}


Berdasarkan tabel 4.13 di atas maka diperoleh model persamaan regresi linear berikut :

$$
\mathrm{Y}=0,328+0,254 \mathrm{X}_{1}+0,329 \mathrm{X}_{2}+0,235 \mathrm{X}_{3}+0,107 \mathrm{X} 4
$$

Persamaan regresi tersebut diperoleh nilai konstanta sebesar ( $\beta$ o) sebesa0,328, artinya persepsi kegunaan $\left(\mathrm{X}_{1}\right)$, persepsi kemudahan $\left(\mathrm{X}_{2}\right)$, keamanan dan kerahasiaan $\left(\mathrm{X}_{3}\right)$ dan pengetahuan wajib pajak terhadap IT (X4) semua bernilai 0 maka nilai variabel intensitas perilaku wajib adalah sebesar 0,328. Koefisien regresi X1 ( $\beta 1$ ) sebesar 0,254 menunjukkan bahwa jika variabel persepsi kegunaan mengalami kenaikan sebesar 1 poin maka variabel intensitas penggunaan e-filing akan mengalami kenaikan sebesar 0,254 dengan asumsi nilai variabel lain tidak mengalami perubahan. Koefisien regresi X2 ( $\left.\beta_{2}\right)$ sebesar 0,329 menunjukkan bahwa jika variabel persepsi kemudahan mengalami kenaikan sebesar 1 poin maka variabel intensitas penggunaan e-filing akan mengalami kenaikan sebesar 0,329 dengan asumsi nilai variabel lain tidak mengalami perubahan.Koefisien regresi $X 3$ ( $\beta 3$ ) sebesar 0,235 menunjukkan bahwa jika variabel persepsi keamanan dan kerahasiaan mengalami kenaikan sebesar 1 poin maka variabel intensitas penggunaan e-filing akan mengalami kenaikan sebesar 0,235 dengan asumsi nilai variabel lain tidak mengalami perubahan.Koefisien regresi X4 ( $\beta 4)$ sebesar 0,107 menunjukkan bahwa jika variabel pengetahuan tentang IT mengalami kenaikan sebesar 1 poin maka variabel intensitas penggunaan e-filing akan mengalami kenaikan sebesar 0,107 dengan asumsi nilai variabel lain tidak mengalami perubahan.

\section{Tabel 8 Rekapitulasi Hasil Pengujian Hipotesis}

\begin{tabular}{clccc} 
Hipotesis & \multicolumn{1}{c}{ Pengaruh } & t-hit & Sig. & Keputusan \\
\hline H1 & Kegunaan --> Intensitas Perilaku & 3,175 & 0,002 & H1 diterima \\
\hline H2 & Kemudahan --> Intensitas Perilaku & 4,734 & 0,000 & H2 diterima \\
\hline H3 & Keamanan \& Kerahasiaan-> Intensitas Perilaku & 3,028 & 0,003 & H3 diterima \\
\hline H4 & Pengetahuan IT --> Intensitas Perilaku & 1,293 & 0,200 & H4 ditolak \\
\hline
\end{tabular}

Diperoleh t-hitung untuk H1 (pengaruh persepsi kegunaan terhadap intensitas perilaku wajib pajak dalam penggunaan e-filing) adalah sebesar 3,175 lebih besar dari pada nilai t-tabel 1,989. Karena nilai nilai t-hitung > t-tabel maka keputusan yang diambil adalah H1 diterima. Artinya data empiris membuktikan variabel persepsi kegunaan e-filing berpengaruh signifikan dan positif terhadap variabel intensitas perilaku wajib pajak dalam penggunaan e-filing di KPP Pratama Raba Bima.

Nilai t-hitung untuk $\mathrm{H} 2$ (pengaruh persepsi kemudahan terhadap intensitas perilaku wajib pajak dalam penggunaan e-filing) adalah sebesar 4,734 lebih besar dari pada nilai t-tabel 1,989. Karena nilai nilai t-hitung > t-tabel maka keputusan yang diambil adalah $\mathrm{H} 2$ diterima. Artinya data empiris membuktikan variabel persepsi kemudahan penggunaan e-filing berpengaruh signifikan dan positif terhadap variabel intensitas perilaku wajib pajak dalam penggunaan e-filing di KPP Pratama Raba Bima.

Nilai t-hitung untuk H3 (pengaruh persepsi keamanan dan kerahasisaan e- filing terhadap intensitas perilaku wajib pajak dalam penggunaan e-filing) adalah sebesar 3,028 lebih besar dari pada nilai t-tabel 1,989. Karena nilai nilai t-hitung > t-tabel maka keputusan yang diambil adalah H3 diterima. Artinya data empiris membuktikan variabel persepsi keamaan dan kerahasiaan e-filing berpengaruh signifikan dan positif terhadap variabel intensitas perilaku wajib pajak dalam penggunaan e-filing di KPP Pratama Raba Bima.

Nilai t-hitung untuk $\mathrm{H} 4$ (pengaruh pengetahuan tentang IT terhadap intensitas perilaku wajib pajak dalam penggunaan e-filing) adalah sebesar 1,293 lebih kecil dari pada nilai t-tabel 1,989. Karena nilai nilai t-hitung < t-tabel maka keputusan yang diambil adalah $\mathrm{H} 4$ ditolak. Artinya data empiris 
membuktikan variabel pengetahuan tentang IT tidak berpengaruh signifikan dan positif terhadap variabel intensitas perilaku wajib pajak dalam penggunaan e-filing di KPP Pratama Raba Bima.

Tabel 8 Nilai Koefisien Determinasi Hasil Analisis Regresi

\begin{tabular}{|l|r|r|r|r|}
\hline Model & \multicolumn{1}{|c|}{$\mathrm{R}$} & $\mathrm{R}$ Square & Adjusted R Square & Std. Error of the Estimate \\
\hline 1 & $.738^{\mathrm{a}}$ & .544 & .522 & .30841 \\
\hline
\end{tabular}

Berdasarkan tabel 4.15 di atas diperoleh nilai koefisien determinasi atau nilai adjusted r-square sebesar 0,522. Hal ini menunjukkan bahwa variasi nilai variabel intensitas perilaku penggunaan e-filing di KPP Pratama Raba Bima mampu dijelaskan oleh variabel persepsi kegunaan, persepsi kemudahan, keamanan dan kerahasiaan dan variabel pengetahuan tentang IT adalah sebesar 52,2\%. Sisanya sebesar $47,8 \%$ dapat dijelaskan oleh variabel-variabel lain di luar model persamaan penelitian ini.

\section{PEMBAHASAN}

\section{1) Pengaruh Persepsi Kegunaan terhadp Intensitas Perilaku Wajib Pajak Dalam Penggunaan E- filing}

Hasil analisis data menunjukkan bahwa variabel persepsi kegunaan e-filing berpengaruh signifikan dan positif terhadap variabel intensitas perilaku wajib pajak dalam penggunaan efiling di KPP Pratama Raba Bima. Hal ini berarti bahwa data empiris menyatakan H1 terbukti. Diperoleh t-hitung sebesar 3,175 lebih besar dari pada nilai t-tabel 1,989. Nilai koefisien regresi variabel persepsi kegunaan bernilai positif. Hal ini berarti bahwa variabel persepsi kegunaan meningkat maka intensitas perilaku Wajib Pajak badan dalam menggunakan $e$ - filing akan mengalami peningkatan pula. Hasil ini dapat diartikan bahwa semakin Wajib Pajak merasa e-filing memiliki manfaat bagi pelaporan SPTnya maka intensitas penggunaan $e$-filing oleh Wajib Pajak badan akan meningkat. Hasil penelitian ini didukung oleh penelitian yang dilakukan oleh Dharma (2016),Nunik (2016), Wibisono dan Agus (2014), Laihad (2013), Desmayanti (2012), Mujiwati (2012) yang memperoleh hasil bahwa terdapat pengaruh positif dari persepsi kegunaan terhadap intensitas perilaku penggunaan e-fiEling. Hal ini berarti bahwa manfaat atau kegunaan suatu sistem merupakan salah satu faktor yang berpengaruh pada pertimbangan pengguna $e$ filing untuk memutuskan untuk menggunakan e-filing dalam pelaporan SPTnya.

\section{2) Pengaruh Persepsi Kemudahan terhadap Intensitas Perilaku Wajib Pajak Dalam Penggunaan E-Filing}

Hasil analisis data dalam penelitian ini menunjukkan bahwa persepsi kemudahan berpengaruh signifikan dan posifif terhadap intensitas perilaku wajib pajak dalam penggunaan $e$ filing. Hasil uji-t menunjukan nilai t-hitung (4.734) > t-tabel (1,989) dengan tingkat sig (signifikansi) $0,000<0,05$ sehingga hipotesis- $\mathrm{H}_{2}$ terbukti. Nilai koefisien regresi variabel persepsi kemudahan bernilai positif, ini dapat diartikan jika variabel Persepsi kemudahan meningkat maka Intensitas Perilaku Wajib Pajak badan dalam menggunakan e-filing akan mengalami peningkatan pula atau semakin tinggi tingkat persepsi kemudahan penggunaan $e$-filing maka wajib pajak akan semakin sering pula menggunakan e-filing. Hasil penelitian ini mendukung penelitian yang dilakukan oleh Dharma dan Noviari (2016), Wahyuni (2015), Laihad (2013), Desmayanti (2012), Noviandini (2012), yang menunjukkan bahwa persepsi kemudahan berpengaruh terhadap intensitas perilaku penggunaan $e$-filing.

\section{3) Pengaruh Keamanan dan Kerahasiaan terhadap Intensitas Perilaku Wajib Pajak Dalam Penggunaan E-Filing}

Hasil analisis data untuk pengujian hipotesis $\mathrm{H}_{3}$ ( uji-t ) dalam penelitian ini menunjukkan bahwa keamanan dan kerahasiaan berpengaruh signifikan dan positif terhadap intensitas perilaku wajib pajak dalam penggunaan e-filing. Pada Tabel 8 tentang hasil uji-t 
menunjukkan nilai t-hitung sebesar 3,028 dengan tingkat sig (signifikansi) 0,003 terhadap intensitas penggunaan $e$-filing. Jika dibandingkan t-tabel dengan t-hitung maka t-tabel $(1,989)<\mathrm{t}$ hitung $(3,028)$ dan nilai sig (signifikansi) $0,003<$ alpha 0,05 sehingga hipotesis (H3) terbukti, ini berarti bahwa keamanan dan kerahasiaan berpengaruh signifikan dan positif terhadap intensitas perilaku wajib pajak dalam penggunaan e-filing. Sehingga dapat disimpulkan bahwa semakin tinggi tingkat keamanan dan kerahasiaan data wajib pajak maka akan semakin tinggi pula tingkat intensitas perilaku penggunaan $e$-filing.

Hasil penelitian ini mendukung penelitian yang dilakukan oleh Dharma dan Noviari(2016), Wahyuni (2015), Wibisono (2014), Salim (2013), Desmayanti (2012), Mujiyati (2011) yang menyatakan bahwa terdapat pengaruh kerahasiaan dan keamanan terhadap intensitas perilaku dalam penggunaan $e$-filing, semakin aman dan terjamin kerahasiaan sistim $e$-filing, maka wajib pajak akan semakin sering pula menggunakan e-filing. Hasil penelitian berbeda dengan yang dilakukan oleh Sugihanti (2011) yang menyatakan bahwa keamanan dan kerahasiaan tidak berpengaruh terhadap intensitas perilaku wajib pajak dalam penggunaan $e$-filing, hal ini karena persepsi seseorang mengenai keamanan dan kerahasiaan dari e-filing berbeda-beda meskipun mayoritas sudah memiliki tingkat percayaan yang tinggi namun masih ada responden yang meragukan.

\section{4) Pengaruh Pengetahuan Wajib Pajak pada Ilmu Teknologi terhadap Intensitas Wajib Pajak Dalam Penggunaan E-Filing}

Hasil analisis data untuk hipotesis H4 hasil analisis menunjukkan bahwa pengetahuan tentang IT tidak berpengaruh signifikan dan positif terhadap variabel intensitas perilaku wajib pajak dalam penggunaan e-filing di KPP Pratama Raba Bima. Hasil uji t menunjukkan nilai t-hitung sebesar 1,293 lebih kecil daripada nilai t-tabel 1,989. Karena nilai nilai t-hitung < t-tabel maka keputusan yang diambil adalah $\mathrm{H} 4$ tidak terbukti. Artinya data empiris membuktikan variabel pengetahuan tentang IT tidak berpengaruh signifikan dan positif terhadap variabel intensitas perilaku wajib pajak dalam penggunaan e-filing di KPP Pratama Raba Bima.

\section{KESIMPULAN DAN SARAN}

\section{Kesimpulan}

Berdasarkan hasil analisis diperoleh kesimpulan bahwa persepsi kegunaan berpengaruh signifikan dan positif terhadap intensitas perilaku wajib pajak dalam penggunaan e-filing, artinya semakin baik persepsi kegunaan wajib pajak pada penggunaan e-filing maka akan semakin sering wajib pajak menggunakan e-filing. Dengan demikian hipotesis pertama yang menyatakan bahwa ada pengaruh persepsi kegunaan terhadap intensitas penggunaan e-filing, diterima.

Penelitian ini membuktikan persepsi kemudahan berpengaruh signifikan dan positif terhadap intensitas perilaku wajib pajak dalam penggunaan e-filing, semakin meningkatnya persepsi kemudahan wajib pajak dalam penggunaan $e$-filing maka akan semakin meningkat pula wajib pajak menggunakan $e$-filing, atau dapat diartikan semakin wajib pajak mempersepsikan e-filing itu mudah digunakan maka intensitas penggunaan wajib pajak akan meningkat pada $e$-filing. Dengan demikian hipotesis kedua yang menyatakan bahwa ada pengaruh antara persepsi kemudahan terhadap intensitas penggunaan e-filing di KPP Pratama Raba Bima, diterima.

Keamanan dan kerahasiaan berpengaruh signifikan dan positif terhadap intensitas perilaku wajib pajak dalam penggunaan $e$-filing, semakin tinggi tingkat keamanan dan kerahasiaan data wajib pajak maka akan semakin tinggi pula tingkat intensitas perilaku penggunaan e-filing. Jika wajib pajak merasakan tingkat keamanan dan kerahasiaan terhadap sistim e-filing semakin baik, maka wajib pajak akan bersedia menggunakan fasilitas e-filing dalam melaporkan kewajiban perpajakan, sehingga dapat 
meningkatkan intensitas wajib pajak dalam menggunakan e-filing. Dengan demikian hipotesis ketiga yang menyatakan bahwa ada pengaruh keamanan dan kerahasiaan data wajib pajak terhadap intensitas penggunaan $e$-filing, diterima.

Pengetahuan wajib pajak tentang IT tidak berpengaruh signifikan terhadap intensitas perilaku wajib pajak badan dalam penggunaan e-filing pada Kantor Pelayanan Pajak Pratama Raba Bima. Hal ini berarti bahwa perubahan pengetahuan wajib pajak tentang IT tidak begitu mempengaruhi intensitas perilaku wajib pajak badan dalam penggunaan e-filing. Tingginya pengetahuan wajib pajak tidak menjamin wajib pajak tersebut melakukan pelaporan tepat waktu dalam pelaporan pajak menggunakan $e$-filing, sehingga tingkat intensitas dalam menggunakan $e$-filing tidak maksimal. Dengan demikian hipotesis keempat yang menyatakan bahwa tidak ada pengaruh pengetahuan wajib pajak terhadap intensitas dalam penggunaan $e$-filing, ditolak

\section{Saran}

Penelitian selanjutnya dapat mengembangkan variabel penelitian diluar yang digunakan dalam penelitian ini, penelitian selanjutnya dapat meneliti variabel kecepatan dalam penggunaan fasilitas $e$ filing, dapat memperluas lingkup penelitian dengan menambah obyek seperti kabupaten/kota sepulau Sumbawa dan Lombok atau Kabupaten/Kota di Propinsi Nusa Tenggara Barat dalam wilayah kerja Kanwil DJP NUSRA, dan dapat meneliti dengan menggunakan pendekatan kualitatif untuk melihat secara mendalam bagaimana pengaruh intensitas perilaku dalam penggunaan $e$-filing.

\section{DAFTAR PUSTAKA}

Chen, Shin-Chih, Shing-Han Li, and Chien-Yi Li. 2011. Recent Related Reseach in Technology Acceptance Model: A Literature Review. Australian Journal of Business and Management Reseach, Vol.1 No. 9: 124-127.

Davis, F.D. 1989. "Perceived Usefulness, Perceived Ease of Use, and Acceptance of Information System Technologi. " MIS Quarterly. Vol.13, No.3:.319-339.Deloitte \& Touche LLP.2008. E-filing in the Netherlands.Part of The Move Tax Forward Series, 1-2

Direktorat Jenderal Pajak. 2005. Peraturan Direktur Jenderal Pajak Nomor KEP-05/PJ/2005 tentang Tata Cara Penyampaian Surat Pemberitahuan secara Elektronik (e-filing) melalui Perusahaan Penyedia Jasa Aplikasi: http://kanwiljogja.pajak.go.id/ppajak.php?id=9334, 2017.

Dewi, A.A, Ratih Khomalyana. 2009. Analisis Faktor-faktor yang mempengaruhi penerimaan Wajib Pajak terhadap penggunaan E-Filing( Fakultas Ekonomi. Universitas Diponegoro. Tembalang.

Desmayanti, Esy. 2012. Faktor-faktor yang mempengaruhi penggunaan fasilitas e-filing oleh wajib pajak sebagai sarana penyampaian SPT Masa Secara Online dan Realtime (Kajian Empiris di Kota Semarang. Universitas Diponegoro. Jurnal Riset Akuntansi Indonesia. Vol.1 No.1 : 1-12.

Dharma dan Noviari. 2016. Faktor-faktor yang berpengaruh pada intensitas penggunaan e-filing oleh wajib pajak orang pribadi. Universitas Udayana. Jurnal Akuntansi. Vol.17 No.2 : 1342-1370.

Hamlet C, Strube H. (2000).Community banks go online. ABA Banking Journal's 2000 White Paper Banking on the interest, 1:61-65

Indriantoro, Nur dan Supomo, Bambang. 2014. Metodologi Penelitian Bisnis untuk Akuntansi dan Manajemen.Yogyakarta : BPFE

Laihad, Risal C.Y. 2013, Pengaruh Perilaku Wajib Pajak Terhadap Penggunaan e-filing wajib Pajak di Kota Manado.Vol.1 No.3: 44-51

Mujiyati. 2012. Faktor-faktor yang mempengaruhi penggunaan e-filing bagi wajib pajak Orang Pribadi (studi pada KPP Surakarta). ISSN 2460-0784 
Noviandini, Nurul Citra. 2012. Pengaruh Persepsi Kebermanfaatan, Persepsi Kemudahan Penggunaan, dan Kepuasan Wajib Pajak Terhadap Penggunaan E-Filing bagi Wajib Pajak di Yogyakarta. Vol.1 No.1: 15-22

Sukandarrumidi, 2006. Metodologi Penelitian, Petunjuk Praktis untuk Peneliti Pemula.Yogyakarta : Gajah Mada University Press.

Susanto, Nugraha Agung. 2011. Analisis Perilaku Wajib Pajak terhadap Penerapan Sistem E-filing Direktorat Jenderal Pajak. (Tesis Fakultas Ekonomi, Universitas Indonesia).

Sugiyono. 2014. Metode Penelitian Kuantitatif, Kualitatif dan R\&D. Bandung. Alfabeta.

Wahyuni, Resky. 2015. Pengaruh Persepsi Kegunaan, Kemudahan Dan Kerahasiaan, Dan Kecepatan Terhadap Intensitas Perilaku Dalam Penggunaan E-Filing (studi pada wajib pajak orang pribadi KPP Pratama Pekanbaru), Vol. 2 No.2 : 1-15.

Wiyono, Gendro. 2011. Merancang Penelitian Bisnis dengan Alat Analisis SPSS dan Smart PLS. Yogyakarta : UPP STIM YKPN

Wibisono, Lisa Tamara. 2014. Analisis Faktor-faktor yang mempengaruhi Minat Wajib Pajak dalam penggunaan e-filing di Surabaya. Tax \& Accounting Review,Vol.4 No.1: 1-15 